\title{
PRODUKTIVITAS PRIMER PERAIRAN DANAU SIBILI KECAMATAN TAWAELI, KOTA PALU, SULAWESI TENGAH
}

\section{Primary Productivity of Lake Sibili Tawaeli District, Palu City, Central Sulawesi}

\author{
Agus Salim Al-Bandjari dan Asri P. Paserang \\ Jurusan Biologi Fakultas Matematika dan Ilmu Pengetahuan Alam Universitas Tadulako Tondo \\ Palu, Sulawesi Tengah 94118
}

\begin{abstract}
Keywords: Primary productivity, Phytoplankt on, Lake Sibili, Palu City

The research "Primary Productivity of Lake Sibili of Tawaeli District, Palu City, Central Sulawesi" was carried out from January to February 2019. This study aims to determine the primary productivity of waters and the physical and chemical parameters of Lake Sibili and as a first step in the use of Lake Sibili sustainable. This study was carried out using the method of oxygen light bottles and dark bottles. The results of the research have shown that station III has the highest net photosynthesis with a value of $1.875 .0 \mathrm{mgC} / \mathrm{m} 3 /$ day (Table 2) this is caused by the temperature and $\mathrm{pH}$ of the station is relatively high which has an average temperature of $30.3^{\circ} \mathrm{C}$ and average $\mathrm{pH}-7.6$ so that this can increase the rate of photosynthetic activity by phytoplankton while the lowest net photosynthetic value is at station I with a value of $812.4 \mathrm{mgC} / \mathrm{m} 3 /$ day which has a relatively lower temperature and $\mathrm{pH}$ compared to other stations which have an average temperature average of $28.9^{\circ} \mathrm{C}$ and average $\mathrm{pH}$ 7. so that based on primary productivity values obtained during the study, the waters of the lake Sibili can be categorized as Eutrophic waters.
\end{abstract}

\section{ABSTRAK}

Kata Kunci: Produktivitas primer, Fitoplankton, Danau Sibili, Kota Palu
Penelitian yang berjudul "Produktivitas Primer Perairan Danau Sibili Kecamatan Tawaeli Kota Palu Sulaawesi Tengah" telah dilaksanakan dari bulan Januari hingga Februari 2019. Penelitian ini bertujuan untuk mengetahui produktivitas primer perairan serta parameter fisika dan kimia danau Sibili dan sebagai langkah awal dari proses pemanfaatan danau Sibili yang berkelanjutan. Penelitian ini dilakukan dengan metode oksigen botol terang dan botol gelap. Hasil penelitian yang telah dilakukan diketahui stasiun III memiliki fotosintesis bersih tertinggi dengan nilai $1,875.0 \mathrm{mgC} / \mathrm{m} 3 /$ hari (Tabel 2) hal ini disebabkan oleh suhu dan $\mathrm{pH}$ pada stasiun tersebut relatif tinggi yaitu memiliki nilai ratarata suhu 30,3 oC dan $\mathrm{pH}$ rata-rata 7,6 sehingga hal ini dapat meningkatkan laju aktivitas fotosintesis oleh fitoplankton sedangkan nilai fotosintesis bersih terendah berada pada stasiun I dengan nilai $812,4 \mathrm{mgC} / \mathrm{m} 3 /$ hari yang mana memiliki suhu dan $\mathrm{pH}$ relatif lebih rendah dibandingkian stasiun lainnya yaitu memiliki suhu rata-rata 28,9 oC dan $\mathrm{pH}$ rata-rata 7 . sehingga berdasarkan nilai produktivitas primer yang diperoleh selama penelitian, maka perairan danau Sibili dapat dikategorikan sebagai perairan Eutrofik

"Corresponding Author : agussalimalbandjari@gmail.com 


\section{PENDAHULUAN}

Danau adalah salah satu bentuk ekosistem yang menempati daerah yang relatif kecil pada permukaan bumi dibandingkan dengan habitat laut dan daratan. Bagi manusia kepentingannya jauh lebih berarti dibandingkan dengan luas daerahnya. Keberadaan ekosistem danau memberikan fungsi yang menguntungkan bagi kehidupan manusia (rumah tangga, industri, dan pertanian) (Kumurur, 2002).

Produktivitas primer merupakan hasil perubahan energi cahaya matahari menjadi energi kimia dalam tubuh organisme autotrof perairan tersebut melalui fotosintesis (Pitoyo dan Wiryanto, 2002). Lebih lanjut Hariyadi dkk., (2010), menjelaskan tingkat produktivitas primer suatu perairan memberikan gambaran bahwa suatu perairan cukup produktif dalam menghasilkan biomassa tumbuhan, termasuk pasokan oksigen yang dihasilkan dari proses fotosintesis.

Dengan tersedianya biomassa tumbuhan dan oksigen yang cukup dapat mendukung perkembangan ekosistem perairan.

Fitoplankton mempunyai peran penting dalam rantai makanan di perairan karena mampu mengubah bahan anorganik menjadi bahan organik melalui proses fotosintesis. Bahan organik dari fitoplankton tersebut dimanfaatkan oleh zooplankton maupun ikan di perairan sebagai sumber makanan, sehingga kelimpahan fitoplankton menjadi penting bagi potensi sumber makanan ikan di alam. Faktor-faktor yang mempengaruhi produktivitas primer yaitu cahaya matahari, suhu, oksigen terlarut, $\mathrm{pH}$, serta struktur komunitas lainnya yang mampu beradaptasi di ekosistem perairan (habitatnya) (Andriani dkk., 2017).

Pemanfaatan potensi perairan danau antara lain sebagai kawasan budidaya periakanan memerlukan bentuk pengelolaan yang tepat sehingga dapat dimanfaatkan secara optimal dan berkesinambungan. Keberadaan fitoplankton pada ekosistem perairan menjadi tolok ukur terhadap kualitas air yang dapat mempengaruhi tingkat produktivitas perairan (Suwangsa, 2006).

Saat ini data ilmiah yang memberikan keterangan mengenai produktivitas primer perairan di kawasan danau Sibili belum tersedia padahal ketersediaan data dan informasi ini sangat dibutuhkan dalam rangka pemanfaatan potensi perairan danau tersebut. Oleh karena itu penelitian ini perlu dilakukan agar segala informasi mengenai produktivitas primer perairan yang dihasilkan danau Sibili dapat menjadi solusi bagi masyarakat sekitar sehingga membantu dalam memanfaatkan potensi danau Sibili dengan sebaik-baiknya dan dapat memberi kesadaran banyak pihak agar dapat memelihara, menjaga dan merawat keberadaan danau. 


\section{BAHAN DAN METODE}

Penelitian ini telah dilaksanakan pada bulan Januari sampai Februari 2019. (Gambar 1). Alat yang digunakan dalam penelitian ini meliputi alat untuk pengukuran produktivitas primer perairan serta pengukuran parameter fisika dan kimia perairan, diantaranya Water sampler digunakan untuk mengambil sampel air, botol You-C 1000 ukuran $150 \mathrm{ml}$ yang terdiri dari botol terang (light bottle), botol gelap (dark bottle), satu botol disediakan untuk initial bottle sebagai DO awal. DO meter untuk mengukur kadar oksigen terlarut di suatu perairan, kertas lakmus $(\mathrm{pH})$ sebagai alat ukur derajat keasaman $(\mathrm{pH})$, Secchi disk digunakan untuk mengukur kecerahan perairan, thermometer digunakan untuk pengukuran suhu, tali rafia digunakan dalam proses inkubasi di dalam perairan, alumunium foil digunakan untuk membungkus botol gelap, alat tulis untuk mencatat hasil yang di dapatakan dan kamera untuk mendokumentasikan kegiatan selama penelitian.

\section{Prosedur Penelitian}

Stasiun I terletak disekitar inlet dan outlet danau yang mana juga berdekatan dengan rawa, stasiun II terletak disekitar dermaga, stasiun III terletak disekitar perairan yang dipenuhi oleh formasi tumbuhan air Eichhornia crassipes (enceng gondok) dan permukiman warga dan stasiun IV berada pada lokasi pemancingan. Data yang diamati meliputi ISSN-P : 1978-6417; ISSN-E : 2580-5991 produktivitas primer perairan serta data pengukuran faktor fisika dan kimia yang meliputi suhu, kecerahan, $\mathrm{pH}$ dan DO (Dissolved oxygen). Pengambilan sampel dilakukan selama tiga minggu dengan perlakuan satu minggu per satu kali pengambilan.

\section{Produktivitas Primer Perairan}

Pada masing-masing stasiun dilakukan pengambilan sampel air menggunakan water sampler pada kedalaman $50 \mathrm{~cm}$, setelah itu sampel air dimasukkan ke dalam botol oksigen yange terdiri dari botol inisial (IB), gelap (DB) dan terang (LB) sampai penuh dan dihindari adanya gelembung udara. Air dalam botol oksigen (IB) diukur kadar oksigen terlarutnya sebagai kadar DO awal. Kemudian botol oksigen gelap dan terang yang telah diisi penuh sampel air, disuspensikan ke dalam air sesuai dengan kedalaman pengambilan sebelumnya. Selanjutnya di inkubasi selama 4 jam, setelah dilakukan inkubasi selama 4 jam, kemudian diangkat ke atas permukaan, lalu diukur DO pada botol oksigen gelap dan terang tersebut sebagai kadar DO akhir, kemudian di catat hasilnya dan dianalisa data yang dihasilkan dengan rumus yang telah ada (Hardiyanto dkk., 2012).

\section{Parameter fisika dan kimia}

Parameter fisika dan kimia perairan diukur pada permukaan perairan dan dilakukan pada saat cahaya matahari maksimal 
yaitu pada siang hari mulai pukul 13.00 sampai 13.40 Wita dengan selang waktu 10 menit dari stasiun satu kestasiun lainnya.

Pengukuran parameter fisika perairan dilakukan pada setiap stasiun yang meliputi kecerahan dan suhu dilakukan secara langsung menggunakan alat pengukuran masing-masing. Untuk pengukuran parameter kimia perairan yang meliputi $\mathrm{pH}$ dan oksigen terlarut juga dilakukan secara langung ditempat pengambilan sampel dengan menggunakan alat pengukuran masingmasing.

\section{Analisis Data}

Produkivitas primer perairan dianalisis besarnya respirasi dan aktivitas gross fotosintesis (Wetzel dan Likens, 1991) yaitu sebagai berikut :

$$
\begin{array}{ll}
\text { Respirasi } & =I B-D B \\
\text { GPP } & =L B-D B \\
\text { NPP } & =(G P P)-(\text { Respirasi })
\end{array}
$$

\section{HASIL}

\section{Produktivitas primer perairan}

Dari hasil perhitungan laju respirasi, GPP (Gross primary productivity) dan NPP (Net primary productivity) yang telah dilakukan di danau Sibili dengan menggunakan botol oksigen terang dan gelap diperoleh data pada tabel 1 .:

$$
\begin{aligned}
& \text { Keterangan : } \\
& \text { Respirasi= Konsumsi oksigen pernapasan } \\
& \text { GPP } \quad=\text { Produktivitas primer kotor } \\
& \text { NPP } \quad=\text { Produktivitas primer bersih } \\
& \begin{array}{ll}
\text { IB } \quad \text { Kadar oksigen awal } \\
\text { DB } \quad=\text { Kadar oksigen akhir botol gelap } \\
\text { LB } \quad \text { Kadar oksigen akhir botol terang }
\end{array}
\end{aligned}
$$

Setelah melakukan penghitungan diatas, dilanjutkan prosedur penghitungan produktivitas primer untuk mendapatkan satuan $\mathrm{mgC} / \mathrm{m}^{3 /}$ hari, menurut (Umaly \& Cuvin, 1998) dengan rumus :

$$
F B=\frac{O^{2} B T-O^{2} B G}{(p Q)(t)} \times 0,375 \times 1000
$$

Keterangan :

$$
\begin{array}{ll}
\mathrm{FB} & =\text { Fotosintesis bersih }\left(\mathrm{mgC} / \mathrm{m}^{3} / \mathrm{jam}\right) \\
\mathrm{pQ} & =\text { Koefisien fotosintesis }(1.2) \\
\mathrm{t} & =\text { Lama inkubasi } \\
0,375 & =\text { Koefisien konversi oksigen menjadi } \\
\text { karbon } & \\
1000 & =\text { Konversi liter menjadi } \mathrm{m}^{3}
\end{array}
$$

Untuk mendapatkan nilai produktivitas primer dalam satuan hari maka nilai per jam harus dikalikan dengan 8 (lama cahaya matahari maksimal) (Asih dkk,. 2007).

Tabel 1. Hasil perhitungan laju Respirasi, Gpp dan Npp

\begin{tabular}{llll}
\hline \multirow{4}{*}{ Ulangan 1 } & Respirasi & 1,15 & $\mathrm{mg} / \mathrm{L}$ \\
\cline { 2 - 4 } & GPP & 1,9 & $\mathrm{mg} / \mathrm{L}$ \\
\cline { 2 - 4 } & $\mathrm{NPP}$ & 0,75 & $\mathrm{mg} / \mathrm{L}$ \\
\hline \multirow{3}{*}{ Ulangan 2 } & Respirasi & 1,6 & $\mathrm{mg} / \mathrm{L}$ \\
\cline { 2 - 4 } & $\mathrm{GPP}$ & 2,35 & $\mathrm{mg} / \mathrm{L}$ \\
\cline { 2 - 4 } & $\mathrm{NPP}$ & 0,75 & $\mathrm{mg} / \mathrm{L}$ \\
\hline \multirow{3}{*}{ Ulangan 3 } & Respirasi & 1,52 & $\mathrm{mg} / \mathrm{L}$ \\
\cline { 2 - 4 } & GPP & 2,67 & $\mathrm{mg} / \mathrm{L}$ \\
\cline { 2 - 4 } & $\mathrm{NPP}$ & 0,92 & $\mathrm{mg} / \mathrm{L}$ \\
\hline
\end{tabular}


Tabel 2. Hasil pengukuran produktivitas primer

\begin{tabular}{cccc}
\hline \multirow{2}{*}{ Stasiun } & \multicolumn{3}{c}{ Ulangan $\left(\mathrm{mgC} / \mathrm{m}^{3 /}\right.$ hari $)$} \\
\cline { 2 - 4 } & 1 & 2 & 3 \\
\hline I & 812,4 & $1.312,5$ & $1.687,5$ \\
\hline II & $1.312,5$ & $1.734,9$ & $1.374,9$ \\
\hline III & $1.374,9$ & $1.562,4$ & $1.875,0$ \\
\hline IV & $1.249,8$ & $1.624,8$ & $1.749,9$ \\
\hline
\end{tabular}

Nilai rata-rata GPP tertinggi yang diterima fitoplankton dari hasil fotosintesis adalah 2,67 $\mathrm{mg} / \mathrm{L}$ dan nilai NPP atau jumlah bahan oraganik yang disimipan setelah dikurangi dengan jumlah yang terpakai untuk respirasi tertinggi terjadi pada ulangan ketiga yaitu adalah $0,92 \mathrm{mg} / \mathrm{L}$ hal ini karena intensitas cahaya pada ulangan ketiga sangat cerah sehingga proses fotosintesis fitoplankton berjalan dengan baik dibandingkan ulangan sebelumnya. sedangkan untuk jumlah oksigen tertinggi yang digunakan untuk proses respirasi adalah 1,52 $\mathrm{mg} / \mathrm{L}$. Namun dapat dilihat bahwa tidak adanya perubahan yang sangat signifikan terhadap nilai rata-rata pada tiap pengulangan.

Hasil perhitungan produktivitas primer atau fotosintesis bersih dalam satuan $\mathrm{mgC} / \mathrm{m}^{3 /}$ hari, disajikan dalam tabel 2 . Hasil pengukuran fotosintesis bersih perairan danau Sibili dapat diketahui pada Stasiun I fotosintesis bersih berkisar 812,4-1.687,5 $\mathrm{mgC} / \mathrm{m}^{3 /}$ hari, stasiun II 1.312,5-1.374,9 $\mathrm{mgC} / \mathrm{m}^{3 /}$ hari, stasiun III 1.374,9-1.875,0 $\mathrm{mgC} / \mathrm{m}^{3 /}$ hari dan stasiun IV 1.249,8-1.749,9 $\mathrm{mgC} / \mathrm{m}^{3 /}$ hari (Tabel 2).

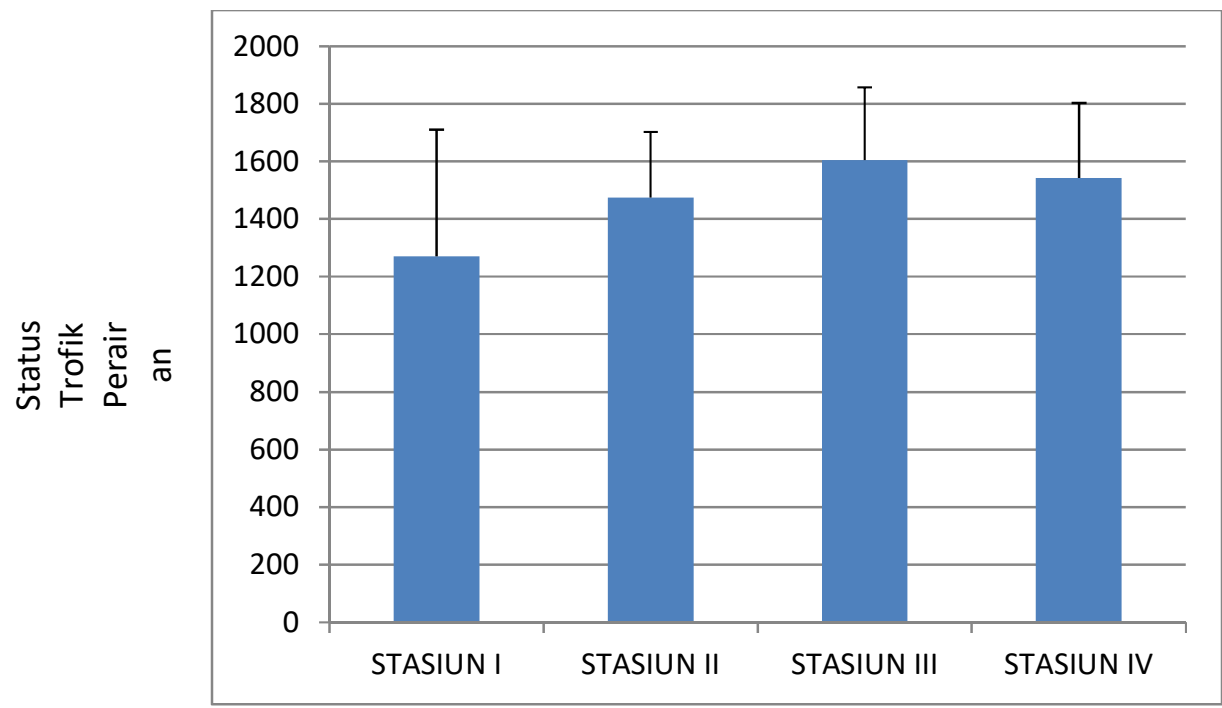

Gambar 2. Grafik perbandingan fotosintesis bersih pada tiap pengulangan

$\begin{array}{llll}\text { Berdasarkan penelitian yang telah } & \text { bersih oleh fitoplankton. akan tetapi dapat } \\ \text { dilakukan, lokasi stasiun tidak } & \text { diketahui pada stasiun III memiliki } \\ \text { berpengaruh nyata terhadap fotosintesis } & \text { fotosintesis bersih tertinggi dibandingkan }\end{array}$


dengan stasiun lainnya dan stasiun I

memiliki fotosintesis terendah

dibandingkan dengan stasiun lainnya.

\section{Parammeter fisika dan kimia}

Hasil pengamatan parameter fisika dan kimia perairan danau Sibili ditunjukkan dalam tabel 3 .

Tabel 3. Parammeter fisika dan kimia peraira

\begin{tabular}{cccccc}
\hline Ulangan & Stasiun & Kecerahan & Suhu & $\mathrm{pH}$ & $\mathrm{DO}$ \\
\hline \multirow{3}{*}{1} & 1 & & $28,8^{\circ} \mathrm{C}$ & 7 & $5,7 \mathrm{mg} / \mathrm{L}$ \\
& 2 & \multirow{2}{*}{$50 \mathrm{~cm}$} & $28,8^{\circ} \mathrm{C}$ & 8 & $5,9 \mathrm{mg} / \mathrm{L}$ \\
& 3 & & $30,1^{\circ} \mathrm{C}$ & 8 & $6,1 \mathrm{mg} / \mathrm{L}$ \\
& 4 & & $29,9^{\circ} \mathrm{C}$ & 8 & $6,0 \mathrm{mg} / \mathrm{L}$ \\
\hline \multirow{2}{*}{2} & 1 & & $29,1^{\circ} \mathrm{C}$ & 7 & $5,9 \mathrm{mg} / \mathrm{L}$ \\
& 2 & \multirow{2}{*}{$50 \mathrm{~cm}$} & $28,5^{\circ} \mathrm{C}$ & 7 & $6,0 \mathrm{mg} / \mathrm{L}$ \\
& 3 & & $29,7{ }^{\circ} \mathrm{C}$ & 8 & $5,7 \mathrm{mg} / \mathrm{L}$ \\
& 4 & & $31,1^{\circ} \mathrm{C}$ & 8 & $6,2 \mathrm{mg} / \mathrm{L}$ \\
\hline \multirow{3}{*}{3} & 1 & & $28,8^{\circ} \mathrm{C}$ & 7 & $5,9 \mathrm{mg} / \mathrm{L}$ \\
& 2 & \multirow{2}{*}{$50 \mathrm{~cm}$} & $29,9{ }^{\circ} \mathrm{C}$ & 8 & $5,8 \mathrm{mg} / \mathrm{L}$ \\
& 3 & & $31,2{ }^{\circ} \mathrm{C}$ & 7 & $6,0 \mathrm{mg} / \mathrm{L}$ \\
& 4 & & $31,3{ }^{\circ} \mathrm{C}$ & 7 & $6,2 \mathrm{mg} / \mathrm{L}$ \\
\hline
\end{tabular}

\section{PEMBAHASAN}

\section{Produktivitar primer perairan}

Proses fotosintesis pada fitoplankton hanya dapat dilakukan jika intensitas cahaya matahari mencukupi. Fitoplankton memanfaatkan cahaya matahari untuk menghasilkan bahan organik yang dapat dimanfaatkan baik untuk fitoplankton itu sendiri ataupun organisme lainnya. Itulah sebabnya kehidupan didalam perairan tergantung pada produsen utama dalam hal ini adalah fitoplankton dalam memproduksi senyawa organik yang dibutuhkan oleh mahluk hidup lainnya disuatu perairan.

Menurut Asriana dan Yuliana, (2012) faktor yang mempengaruhi fotosintesis pada fitoplankton diantaranya adalah cahaya, suhu, $\mathrm{pH}$ dan zat hara. Fotosintesis hanya dapat berlangsung bila ISSN-P : 1978-6417; ISSN-E : 2580-5991 intensitas cahaya yang sampai kesuatu sel lebih besar dari pada suatu intensitas tertentu. Hal ini berarti fitoplankton yang produktif hanya berada pada lapisanlapisan air teratas dimana intensirtas cahaya cukup bagi berlangsungnya fotosintsis. Suhu dan $\mathrm{pH}$ air merupakan faktor yang penting bagi pertumbuhan fitoplankton, peningkatan suhu dan $\mathrm{pH}$ pada kisaran toleransi akan meningkatkan laju metabolisme dan aktivitas fotosintesis. Zat hara yang terkandung disuatu perairan juga memiliki peran yang sangat penting bagi pertumbuhan fitoplankton dan berlangsungnya fotosintesis.

Berdasarkan hasil penelitian yang telah dilakukan dapat duketahui bahwa stasiun III memiliki fotosintesis bersih tertinggi dibandingkan stasiun lainnya dengan nilai $1,875.0 \mathrm{mgC} / \mathrm{m} 3 /$ hari (Tabel 2) hal ini 
disebabkan oleh suhu dan $\mathrm{pH}$ pada stasiun tersebut relatif tinggi yaitu memiliki nilai rata-rata suhu $30,3{ }^{\circ} \mathrm{C}$ dan $\mathrm{pH}$ ratarata 7,6 sehingga hal ini dapat meningkatkan laju aktivitas fotosintesis oleh fitoplankton sedangkan nilai fotosintesis bersih terendah berada pada stasiun I dengan nilai $812,4 \mathrm{mgC} / \mathrm{m} 3 /$ hari yang mana memiliki suhu dan $\mathrm{pH}$ relatif lebih rendah dibandingkian stasiun lainnya yaitu memiliki suhu rata-rata $28,9{ }^{\circ} \mathrm{C}$ dan $\mathrm{pH}$ rata-rata 7.

Perbedaan nilai fotosintesis bersih pada tiap stasiun menunjukan adanya karakteristik yang berbeda pada masingmasing stasiun pengambilan, namun dapat diketahui bahwa produktivitas primer pada tiap stasiun tidak memiliki perubahan yang signifikan pada setiap pengulangan (Gambar 2) yaitu tetap berada pada angka $>750$, sehingga berdasarkan nilai produktivitas primer yang diperoleh selama penelitian, perairan danau Sibili dapat dikategorikan sebagai perairan eutrofik, hal ini dapat dilihat berdasarkan klasifikasi tingkat kesuburan produktivitas primer perairan menurut Sari dkk., (2017) yaitu :

Tabel 4. Klasifikasi Tingkat Kesuburan berdasarkan Produktivitas Primer

\begin{tabular}{ll}
\hline $\begin{array}{l}\text { Produktivitas } \\
\text { Primer }\end{array}$ & $\begin{array}{l}\text { Tingkat } \\
\text { kesuburan }\end{array}$ \\
\hline $0-200$ & Oligotrofik \\
\hline $200-750$ & Mesotrofik \\
\hline$>750$ & Eutrofik \\
\hline
\end{tabular}

Perairan eutrofik yaitu perairan yang memiliki produktivitas primer yang tinggi ISSN-P : 1978-6417; ISSN-E : 2580-5991 dan umumnya kaya akan kandungan makanan atau nutrien, karena aktivitas fitoplankton pada perairan tersebut sangat produktif dan ciri umum dari perairan ini adalah airnya terlihat keruh dikarenakan pertumbuhan fitoplakton yang sangat pesat. Selain air didominasi oleh fitoplankton yang tidak ramah lingkungan, perairan eutofik juga merangsang pertumbuhan tanaman air lainnya, hal ini dapat dibuktikan dengan cukup banyaknya formasi tumbuhan air (Eichhornia crassipes) dan kangkung air (Ipomoea aquatica) pada perairan danau Sibili.

Perlu adanya tindakan yang tepat untuk mencegah kondisi perairan menjadi semakin buruk, kondisi seperti ini dapat berakibat negatif bagi kualitas perairan danau Sibili yang mana hal yang sama juga terjadi pada danau Rawa Pening yang dilaporkan oleh (Yuningsih., dkk, 2014) yang menyatakan danau tersebut memiliki tingkat produktivitas primer tertinggi yaitu $3.333,12 \mathrm{mgC} / \mathrm{m}^{3 /}$ hari dan juga tergolong danau eutrofik sehingga memicu pertumbuhan tanaman air yang sangat pesat dikarenakan fitoplankton yang sangat produktif.

\section{Patameter fisika dan kimia}

Hasil pengukuran rata-rata nilai kecerahan pada setiap stasiun menggunakan secchi disk yaitu $50 \mathrm{~cm}$. hal ini dikarenakan substrat dasar perairan yang ada pada danau Sibili didominasi oleh lumpur, aktivitas berlebihan oleh fitoplankton dan kedalaman tertinggi $\pm 2 \mathrm{~m}$ sehingga 
perairan terlihat keruh. Boyd (1990), menyatakan bahwa tingkat kecerahan perairan yang baik untuk plankton secara optimal yaitu $30-50 \mathrm{~cm}$. sehingga dapat diketahui bahwa kecerahan perairan pada danau Sibili tergolong baik untuk pertumbuhan plankton.

Suhu air merupakan salah satu faktor abiotik yang memegang peranan penting bagi keidupan organisme perairan. hasil pengukuran suhu pada tiap stasiun diperairan danau Sibili Kota Palu berkisar antara $28,5{ }^{\circ} \mathrm{C}$ ssampai $31,3{ }^{\circ} \mathrm{C}$. Menurut Reynold (1990), suhu optimum untuk pertumbuhan fitoplankton adalah 25-32 ${ }^{\circ} \mathrm{C}$. Nilai kisaran suhu di perairan danau Sibili kota palu perairan berada pada kisaran suhu yang baik untuk kelangsungan hidup fitoplankton.

Angka derajat keasaman $(\mathrm{pH})$ pada danau Sibili berkisar antara 7 sampai 8 . Menurut PP No. 82 Tahun 2001, derajat keasaman $(\mathrm{pH})$ yang diperlukan untuk mendukung kehidupan perairan yaitu 6-9. Sehingga dapat diketahui bahwa nilai kisaran $\mathrm{pH}$ pada danau Sibili masih tergolong dalam keadaan baik.

\section{KESIMPULAN}

Nilai tertinggi produktivitas primer perairan danau Sibili adalah $1.875,0 \mathrm{mgC} / \mathrm{m}^{3 /}$ hari dan nilai terendah berada pada nilai $812,4 \mathrm{mgC} / \mathrm{m}^{3 /}$ hari. sehingga dapat diketahui bahwa perairan danau Sibili dikategorikan sebagai perairan eutrofik. Berdasarkan pengukuran parameter fisika dan kimia perairan danau Sibili dapat ISSN-P : 1978-6417; ISSN-E : 2580-5991
Nilai oksigen terlaurut yang didapatkan yaitu $5,7 \mathrm{mg} / \mathrm{L}-6,2 \mathrm{mg} / \mathrm{L}$. kandungan $\mathrm{DO}$ diukur pada permukaan perairan, mengingat $\mathrm{DO}$ maksimal perairan terdapat pada tingkatan permukaan. PP No.28 tahun 2001 menyatakan bahwa nilai standar baku mutu untuk kelangsungan hidup perairan sebesar $3 \mathrm{mg} / \mathrm{L}$.

Produktivitas suatu perairan sangat ditentukan oleh sifat fisika dan kimia serta organisme hidup pendukung lainnya. perairan yang miliki sifat fisika dan kimia sangat tinggi ataupun sebaliknya dapat merusak jaringan tubuh fitoplankton, sehingga akan mengganggu proses fotosintesis dan menghambat pembuatan ikatan-ikatan organik yang kompleks dari bahan organik yang sederhana serta akan mengganggu kestabilan perairan itu sendiri (Yuningsih., dkk, 2014). Dari hasil pengukuran parameter fisika dan kimia perairan danau Sibili didapatkan nilai kecerahan, suhu, $\mathrm{pH}$ dan oksigen terlarut rata-rata berada pada nilai standar baku mutu dalam mendukung pertumbuhan fitoplankton.

diketahui bahwa rata-rata nilai kecerahan yaitu $50 \mathrm{~cm}$ tergolong baik, suhu diperairan danau Sibili berkisar antara 28,5-31,3 ${ }^{\circ} \mathrm{C}$ tergolong baik, angka derajat keasaman $(\mathrm{pH})$ pada danau Sibili kota palu berkisar antara 7 sampai 8 tergolong baik serta DO diperairan danau Sibili serta nilai oksigen terlaurut rata-rata berkisar antara $5,7 \mathrm{mg} / \mathrm{L}-6,2 \mathrm{mg} / \mathrm{L}$ tergolong baik 
berdasarkan baku mutu perairan yang optimal.

\section{DAFTAR PUSTAKA}

Andriani, A. Damar, A. Rahardjo, M. F. Simanjuntak C. Asriansyah, A dan Aditriawan, R.M. 2017. Abundance of Phytoplankton and its Role as Fish Food Sources in Pabean Bay, West Java. Jurnal Sumberdaya Akuatik Indopasifik. Volume 1. Nomor 2. Halaman 141.

Asih, P. Muzahar dan Pratomo, A. 2007. Produktivitas primer fitoplankton di perairan Desa Malang Rapat Kabupaten Bintan. Program Studi IImu Kelautan, FIKP, UMRAH.

Asriana dan Yuliana. 2012. Produktivitas Perairan. Bumi Aksara. Jakarta. 278 hlm.

Boyd, C. E. 1990. Water Quality in Ponds For Agricultural. Experiment Stasion. Albama. $482 \mathrm{hlm}$.

Hardiyanto, R. Suherman, H dan Pratama, R. I. 2012. Kajian Produktivitas Primer Fitoplankton Di Waduk Saguling , Desa Bongas Dalam Kaitannya Dengan Kegiatan Perikanan. Jurnal Perikanan dan Kelautan.

Hariyadi S, E. M. Adiwilaga, T. Prartono, S. Hardjoamidjojo dan A. Damar. 2010. Produktivitas Primer Estuari Sungai Cisadane Pada Musim Kemarau. Limnotek. Volume 17. Nomor 1. Halaman 52.

Kumurur, V.A. 2002. Aspek Strategis Pengelolaan Danau Tondano Secara Terpadu. Universitas Sam Ratulangi, Manado.

Peraturan Pemerintah Nomor 82 Tahun 2001 Tanggal 14 Desember 2001
Tentang Pengelolaan Kualitas Air Dan Pengendalian Pencemaran Air.

Pitoyo, A dan Wiryanto, 2002. Primary Productivity of the Cengklik Dam Boyolali. FMIPA. UNS Surakarta.

Reynolds, C. S. 1990. Ecology of Freshwater Phytoplankton. Cambridge University Press. Cambridge. $388 \mathrm{hlm}$.

Sari, D. Y, Haeruddinm \& Rudiyanti, S. 2017. Habitat Quality Review based on Level of Productivity as Utilization Database Coastal Waters Tasikagung Village, Rembang. JOURNAL OF MAQUARES Volume 6, Nomor 4. Halaman 493.

Suwangsa, I. H. 2006. Keanekaragaman Plankton di Perairan Danau Beratan Bali. Skripsi, Program Studi Biologi Jurusan Matematika Dan Ilmu Pengtahuan Alam Fakultas Sains Dan Teknologi. Universitas Islam Negeri Syarif Hidayatullah. Jakarta.

Umaly, R. C. and L. A. Cuvin. 1988. Limnology Laboratory and Field Guide Physico-Chemical Factors, Biology Factors. National Book Store Publ. Manila.

Wetzel, R. G and Likens. 1991. Limnological Analysis. Second edition. Springer-Verlag. New York. USA.

Yuningsih, H. D. Soedarsono, P. Anggoro, S. 2014. Hubungan Bahan Organik Dengan Produktivitas Perairan Pada Kawasan Tutupan Eceng Gondok, Perairan Terbuka Dan Keramba Jaring Apung Di Rawa Pening Kabupaten Semarang Jawa Tengah. Diponegoro Journal Of Maquares. UNDIP. Volume 3. Nomor 1. Halaman

40. 